\title{
Paleoseismology of the Xorxol Segment of the Central Altyn Tagh Fault, Xinjiang, China
}

\author{
Zack Washburn $\left({ }^{1}\right)$, J Ramón Arrowsmith $\left({ }^{2}\right)$, Guillaume Dupont-Nivet $\left({ }^{3}\right)$, Wang Xiao Feng $\left({ }^{4}\right)$, \\ Zhang Yu Qiao $\left({ }^{4}\right)$ and Chen Zhengle $\left({ }^{4}\right)$ \\ ${ }^{1}$ ) Geomatrix Consultants Inc., Costa Mesa, CA, U.S.A. \\ $\left(^{2}\right)$ Department of Geological Sciences, Arizona State University, Tempe, AZ, U.S.A. \\ $\left({ }^{3}\right)$ Paleomagnetic Laboratory «Fort Hoofdijk», Faculty of Earth Sciences, Utrecht University, Netherlands \\ $\left.{ }^{4}\right)$ Institute of Geomechanics, Chinese Academy of Geological Sciences, Beijing, China
}

\begin{abstract}
Although the Altyn Tagh Fault (ATF) is thought to play a key role in accommodating India-Eurasian convergence, little is known about its earthquake history. Studies of this strike-slip fault are important for interpretation of the role of faulting versus distributed deformation in the accommodation of the India- Eurasia collision. In addition, the $>1200 \mathrm{~km}$ long fault represents one of the most important and exemplary intracontinental strike-slip faults in the world. We mapped fault trace geometry and interpreted paleoseismic trench exposures to characterize the seismogenic behavior of the ATF. We identified 2 geometric segment boundaries in a $270 \mathrm{~km}$ long reach of the central ATF. These boundaries define the westernmost Wuzhunxiao, the Central Pingding, and the easternmost Xorxol (also written as Suekuli or Suo'erkuli) segments. In this paper, we present the results from the Camel paleoseismic site along the Xorxol Segment at $91.759^{\circ} \mathrm{E}, 38.919^{\circ} \mathrm{N}$. There evidence for the last two earthquakes is clear and ${ }^{14} \mathrm{C}$ dates from layers exposed in the excavation bracket their ages. The most recent earthquake occurred between 1456 and $1775 \mathrm{cal}$ A.D. and the penultimate event was between 60 and $980 \mathrm{cal}$ A.D. Combining the Camel interpretations with our published results for the central ATF, we conclude that multiple earthquakes with shorter rupture lengths $(\sim 50 \mathrm{~km})$ rather than complete rupture of the Xorxol Segment better explain the paleoseismic data. We found 2-3 earthquakes in the last 2-3 kyr. When coupled with typical amounts of slip per event (5-10 m), the recurrence times are tentatively consistent with 1-2 cm/yr slip rates. This result favors models that consider the broader distribution of collisional deformation, rather than those with northward motion of India into Asia absorbed along a few faults bounding rigid blocks.
\end{abstract}

Key words paleoseismology - Altyn Tagh Fault strike-slip faults - India-Eurasia collision

\section{Introduction}

The sinistral Altyn Tagh Fault (ATF) traverses the northern boundary of Tibet for $>1500 \mathrm{~km}$ and is a major structure in the India-Eurasia con-

Mailing address: Dr. J Ramón Arrowsmith, Department of Geological Sciences, Arizona State University, Tempe, AZ 85287-1404 U.S.A.; e-mail: ramon.arrowsmith@asu.edu tinental collision (e.g., Tapponnier and Molnar, 1977; Peltzer et al., 1989; Yin and Harrison, 2000; Tapponnier et al., 2001; fig. 1). Two competing end-member models have developed that describe how northward convergence of India is accommodated by Tibet and Southern Asia. The first model divides this region into a few rigid blocks bounded by major faults (i.e. Altyn Tagh and Kunlun faults, fig. 1) (e.g., Avouac and Tapponnier, 1993; Tapponnier, et al., 2001). The second model has convergence accommodated by crustal thickening and along numerous minor and a few major faults (e.g., England and Molnar, 1997). Models of the first type are con- 


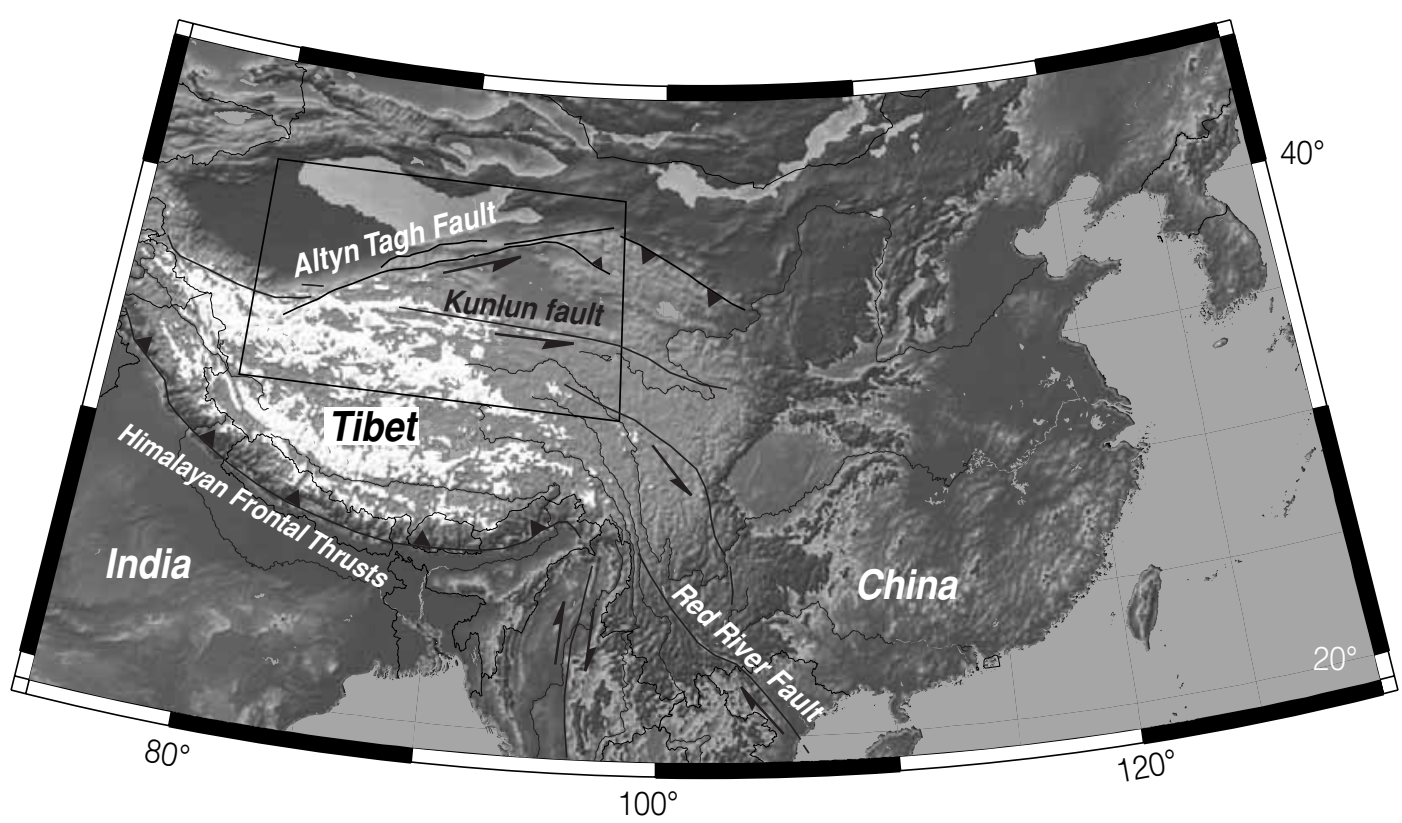

Fig. 1. Overview map showing major structures and topography in the India-Eurasia continental collision zone. Inset shows location of fig. 2. Figure generated from GTOPO30 $1 \mathrm{~km}$ digital elevation data set using GMT (Wessel and Smith, 1995).

sistent with higher slip rates $(\sim 3 \mathrm{~cm} / \mathrm{yr}$ for the ATF) while lower slip rates are consistent with the second type because deformation is distributed instead of localized along a small number of discrete fault planes.

Global seismicity databases (CNSS) and the Chinese Catalog of Historic Strong Earthquakes (2300 B.C. to 1911 A.D.) record no major earthquakes along the ATF. However, we know that large earthquakes have occurred because of moletracks seen on satellite imagery, surface breaks shown by Ge et al. (1992), and limited field investigation by western scientists (Molnar et al., 1987). Despite the clear evidence of active faulting, slip rate determinations are discrepant. Over timescales of $10 \mathrm{~s}-100 \mathrm{~s}$ of kyr, slip rates are inferred to be $2-3 \mathrm{~cm} / \mathrm{yr}$. Peltzer et al. (1989) inferred $\sim 3 \mathrm{~cm} / \mathrm{yr}$ rates in the area of $84^{\circ} \mathrm{E}-92^{\circ} \mathrm{E}$ based on an assumption of initial Holocene age for offset landforms. Recent work has focused on determining the slip rate by dating offset Quaternary landforms using cosmogenic meth- ods. Meriaux et al. $(1999,2000)$ determined 3 $\mathrm{cm} / \mathrm{yr}$ between $85^{\circ} \mathrm{E}$ and $89^{\circ} \mathrm{E}$ and $2-3 \mathrm{~cm} / \mathrm{yr}$ near $90^{\circ} \mathrm{E}$. Merieaux et al. (2003) determined a minimum of $20 \pm 3 \mathrm{~mm} / \mathrm{yr}$ at $94^{\circ} \mathrm{E}$. Chinese earthquake geology studies (mapping, paleoseismic trenching, and ${ }^{14} \mathrm{C}$ ) inferred a minimum rate of $5 \mathrm{~mm} / \mathrm{yr}$ along the entire ATF (Ge et al., 1992). Studies of deformation in the India- Eurasian collision over geodetic timescales (5-10 years; Bendick et al., 2000; Shen et al., 2001; Wang et al., 2001) indicate that distributed deformation in Tibet is an important process because faults such as the ATF have slip rates on the order of $10 \mathrm{~mm} / \mathrm{yr}(9 \pm 5 \mathrm{~mm} / \mathrm{yr}$, Bendick et al., 2000; $9 \pm 2 \mathrm{~mm} / \mathrm{yr}$, Shen et al., 2001). Holt et al. (2000) also used a rate of $10 \pm 8$ $\mathrm{mm} / \mathrm{yr}$ along the ATF in their analysis of the velocity field in Asia.

Two major strike-slip earthquakes have recently occurred in Northern Tibet. The 1997 $M_{w}$ 7.6 Manyi earthquake ruptured for a distance of about $170 \mathrm{~km}$ with peak left-lateral 
slip of about $7 \mathrm{~m}$, apparently reactivating a Quaternary fault (fig. 2; Peltzer et al., 1999). The $2001 M_{w} 7.8$ Kokoxili or Central Kunlun earthquake had a 300-400 km long rupture zone and sinistral slip up to $16.3 \mathrm{~m}$ (Lin et al., 2002; Klinger et al., 2003). It ruptured the eastern portion of the Kunlun Fault (van der Woerd et al., 2002). These earthquakes draw attention to the style of earthquake rupture along the great strike-slip faults of Asia and also to their response to the geodynamic setting. Because the historic record in this region is only complete for about the last 100 years, paleoseismo- logical methods are important for investigating the timing of large ruptures like these and those along neighboring faults.

Earthquake displacements, surface rupture lengths, and recurrence intervals along major strike-slip faults such as the ATF have implications for which geodynamic models better explain continental deformation and for regional earthquake sequences in continental settings. Therefore, we conducted a study of the earthquake geology of the ATF to characterize the seismogenic behavior of this major strike-slip fault. In this paper, we first highlight the geo-

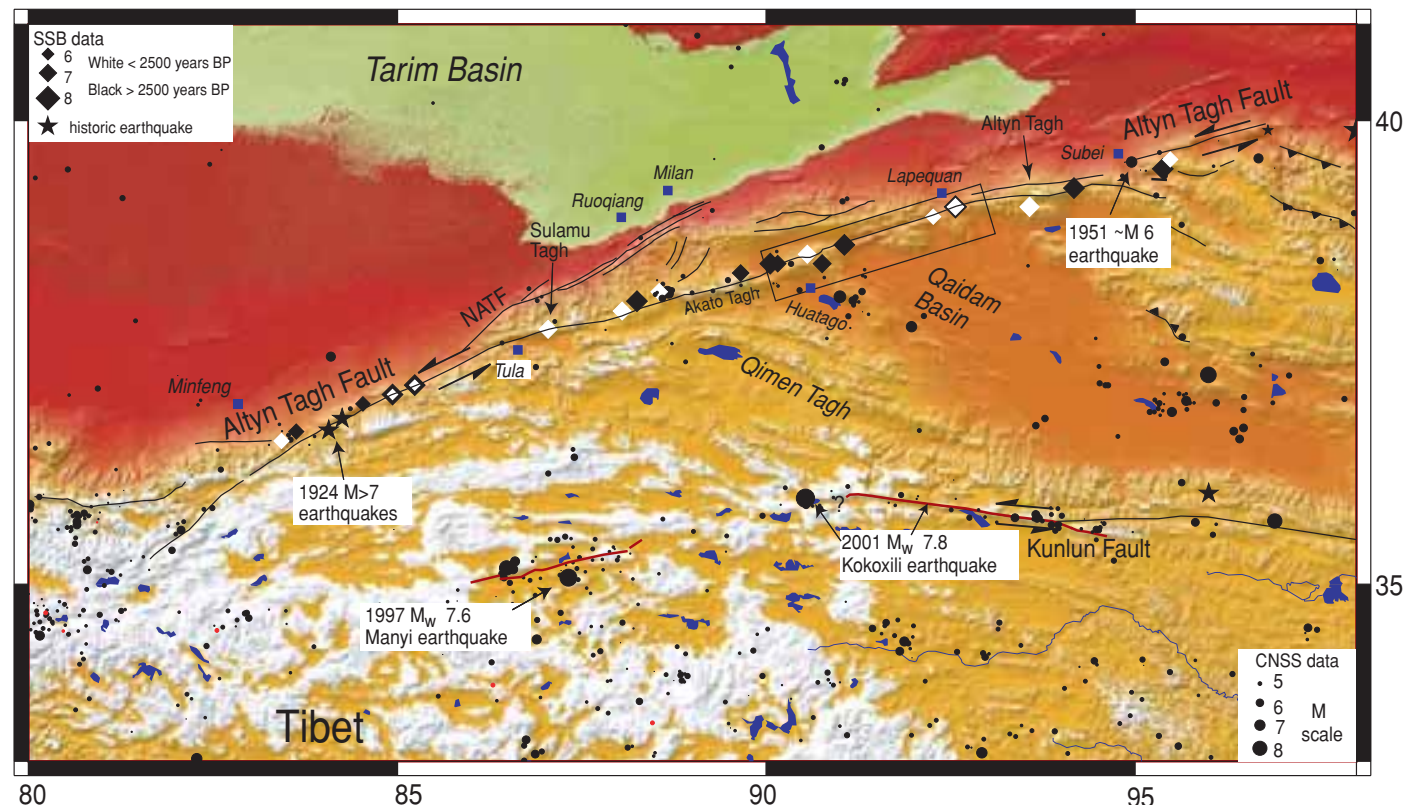

Fig. 2. Overview map showing the Central Altyn Tagh Fault (ATF), location of study area (rectangular box, fig. 3), instrumental seismicity (Council of the National Seismic System (CNSS); http://quake.geo.berkeley.edu/cnss/cata$\log$-search.html), historic earthquakes (Chinese Catalog of Historic Strong Earthquakes 2300 B.C. to A.D., 1991), paleoearthquakes (State Seismological Bureau (SSB); Ge et al., 1992), and major towns. The Ge et al. (1992) data are plotted at the reported locations with their inferred magnitude and color-coded by age range. The events most relevant for this study are $<2500$ years BP (white). The low seismic activity is unexpected because the ATF is thought to accommodate a significant portion of India-Asia convergence. The historical record also shows fewer earthquakes than anticipated. North Altyn Tagh Fault (NATF) mapping from Cowgill et al. (2000). Manyi earthquake surface rupture from Peltzer et al. (1999) and Kokoxili earthquake location and approximate surface rupture are from van der Woerd et al. (2002) and Lin et al. (2002). Base figure generated from GTOPO30 $1 \mathrm{~km}$ digital elevation data set using GMT (Wessel and Smith, 1995). 
metric segmentation of the central ATF by dividing it into three sections (westernmost Wuzhunxiao, the central Pingding, and easternmost Xorxol-also written as Suekuli or Suo'erkuli). Secondly, we present new paleoseismic results from the Xorxol Segment at $91.759^{\circ} \mathrm{E}, 38.919^{\circ} \mathrm{N}$ at the Camel paleoseismic site. Finally, we review results from Washburn et al. (2001) and Washburn (2001), to develop earthquake rupture scenarios for the central ATF. The geometric boundaries and ${ }^{14} \mathrm{C}$ dates defining age ranges for paleoearthquakes imply that one large earthquake rupturing all 3 segments $(270 \mathrm{~km})$ is unlikely. Furthermore, multiple earthquakes with shorter rupture lengths $(\sim 50 \mathrm{~km})$ rather than complete rupture of the Xorxol Segment better explain the paleoseismic data. When coupled with typical amounts of slip per event $(5-10 \mathrm{~m})$, the recurrence times are consistent with $1-2 \mathrm{~cm} / \mathrm{yr}$ slip rates.

\section{Geomorphic and geologic framework}

The study area is located in Xinjiang, Qinghai and Gansu provinces of Western China between $89.619^{\circ} \mathrm{E}, 38.302^{\circ} \mathrm{N}$ and $92.523^{\circ} \mathrm{E}$, $39.138^{\circ} \mathrm{N}$ (figs. 1,2 and 3 ). This is an arid region of alluvial fan and playa environments around $3000 \mathrm{~m}$ in elevation with neighboring glaciated peaks rising up to $5000 \mathrm{~m}$. In the western part of the study area, the ATF passes through a $4000 \mathrm{~m}$ high, axial valley south of Liweiqiming Shan and descends across alluvial fans and saline lakes of the Wuzhunxiao area (figs. 2 and 3). From here, the ATF traverses bedrock and small perched alluvial basins $(<0.5$ $\mathrm{km}^{2}$ ) within an isolated mountain range, marked by the $4800 \mathrm{~m}$ Pingding Shan. From Gobiling, the ATF descends into the alluvium filled strike-slip rift of Xorxol Valley. This straight and distinct tectonic landscape continues east for

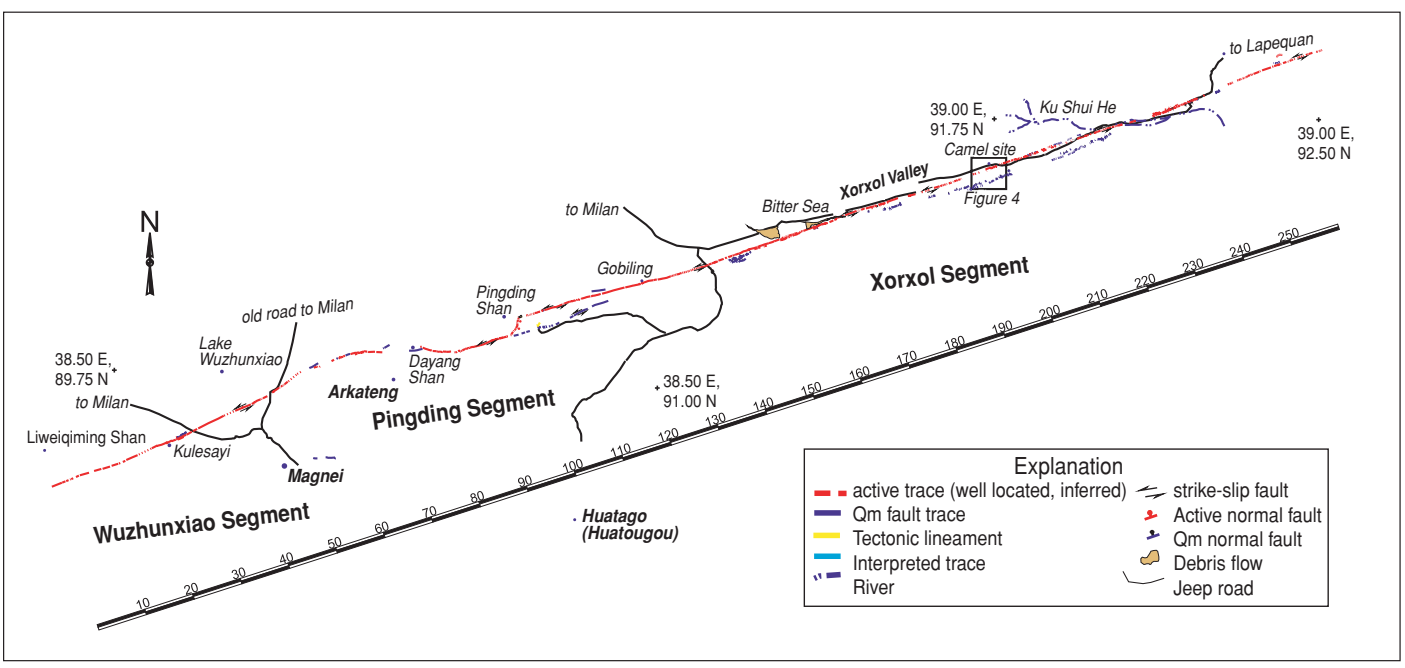

Fig. 3. Fault trace map of Central Altyn Tagh Fault (ATF) showing geometry of most recent and Late Quaternary rupture traces. Major roads, location of geographic landmarks, and towns are also shown for reference. This portion of the ATF is predominantly left lateral and has well-developed strike-slip topography (e.g., Xorxol rift valley). However, it has not produced instrumentally recorded earthquakes $>M 6$. The active trace traverses alluvial flats around Lake Wuzhunxiao and the Bitter Sea and bedrock in the Arkateng and Pingding mountain ranges. Two geometric boundaries are identified: the $\sim 7 \mathrm{~km}$ wide Arkateng Restraining Bend and the $4 \mathrm{~km}$ wide Pingding releasing step. These geometric boundaries de fine the westernmost Wuzhunxiao, the Central Pingding, and the easternmost Xorxol segments. The boundaries serve as a framework for interpreting offset data and estimating rupture extent because such discontinuities commonly act as rupture barriers. 
over $110 \mathrm{~km}$ (figs. 2 and 3). Proterozoic intrusive rocks and slivers of Paleozoic-Mesozoic granitoid, ultramafic, marine carbonate, and ophiolitic rocks comprise the mountains in the study area (Cowgill et al., 2003). Thick Neogene boulder gravels to silts encircle the Proterozoic-Mesozoic mountains and fill adjacent basins. Intense folding of these strata in the Qaidam Basin and throughout the field area indicate a contractional regime (regionally) following deposition of the Neogene units. Relatively thin Quaternary gravels and silts (piedmont deposits and primary and reworked loess) overlie the Neogene strata.

\section{Fault trace mapping and paleoseismic site identification}

In the field, we mapped the fault traces that comprise the individual faults that have had recent rupture based on geomorphic age of the scarps, disruptions of Holocene deposits and landforms. The active trace designation generally refers to surface breaks created by the last 1-3 earthquakes. We have identified the active traces and most Quaternary faults, but may not show all of the early Quaternary faults because we are primarily concerned with the geometry and earthquake history for the last few kyr. In fig. 3, faults labeled Qm are similar in age to or slightly younger than surfaces and deposits of Late Pleistocene and Early Holocene inferred age. These were mapped as unit Qm and are the most extensive of the Quaternary deposits and form broad floors that depositionally abut adjacent hill sides and often de fine a sharp break in slope. They generally have a few to $10 \mathrm{~s}$ of $\mathrm{m}$ incision and may be covered with varnished clasts. Tectonic lineaments refer to suspicious geomorphic alignments that are most likely faults older than Qm.

Our mapping approach was to inspect the principal active traces as identified on CORONA imagery. We mapped the main fault traces, the Quaternary units discussed above, and occasionally obtained bedding or other structural attitudes. We typically covered a $\sim 5 \mathrm{~km}$ wide zone centered over and parallel to the active trace to identify relevant structures and geolog- ic relations. We made many small excavations with shovels to clarify stratigraphic relationships and expose bedding surfaces. These smaller excavations helped add confidence to our geomorphic and stratigraphic-based paleoseismic site decisions. We logged natural and hand-dug exposures, and documented offset (both vertical and horizontal) landforms and strata.

While mapping the fault trace, we looked for sites where landforms indicated that steady accumulation of distinctive sediments would preserve evidence for past ruptures. In a number of excavations at such sites, broken and tilted beds overlain by continuous beds and upward terminations of fault traces identify past earthquakes in excavations. Disruption seen at the same stratigraphic level at several locations and on both trench walls qualifies as a distinct event (after Grant and Sieh, 1994). Organic matter within the stratigraphy was dated using ${ }^{14} \mathrm{C}$ and fine silt was dated by infrared stimulated luminescence (IRSL) (Forman, 1999). We use the $2 \sigma$ calibrated sample ages and OxCal v3.5 (Ramsey, 2000) for timing constraints. We also use a Monte Carlo program that uses ordering constraints to «trim» probability distributions of radiocarbon samples and then yields probabilities for events (Hilley and Young, 2003). This approach allows for more objective event correlation between paleoseismic sites.

\section{Fault trace geometry}

A small-scale representation of the active traces that we mapped is shown in fig. 3. For convenience, we refer to locations along the mapped traces in terms of distance from the western end of the study area. Washburn et al. (2001) described the western $150 \mathrm{~km}$ of the area shown in fig. 3 and established the geometric segmentation. Our subsequent mapping added another $120 \mathrm{~km}$ toward the east (Washburn, 2001). A view along the strike of the active trace in fig. 3 shows a prominent right bend $(65$ to $85 \mathrm{~km})$ and left step $(97 \mathrm{~km})$ in the generally straight Central Altyn Tagh Fault. We followed the conventions of dePolo et al. (1991) and Knuepfer (1989) and identified these discontinuities as geometric bound- 
aries which in turn define the westernmost Wuzhunxiao Segment, the Central Pingding Segment, and the Eastern Xorxol Segment. These segments are not necessarily rupture segments; however, this approach is useful for characterizing fault zones because geometric boundaries may be locations of significant change in slip or moment release (e.g., Wesnousky, 1989; Harris and Day, 1993, 1999). Historical rupture data show that rupture endpoints commonly coincide with geometric boundaries and these boundaries appear to retard rupture (Knuepfer, 1989).

The major geometric boundary in the study area is the Pingding Releasing Step. Here, the active trace jumps from the southern side of Pingding Shan $4 \mathrm{~km}$ north to the active trace that continues to the Xorxol Valley (fig. 3; Washburn, 2001; Washburn et al., 2001). The 3-4 m vertical offset of Holocene-age fan on the southeast side of Pingding Shan, a prominent scarp on the east face of Pingding Shan, and the presence of recent landslides indicate that the normal fault that links the bounding strike-slip faults ruptured recently.
Our mapping stops at $268 \mathrm{~km}$ in a straight and simple portion of the Xorxol Segment (fig. 3 ). This $070^{\circ}$ striking simple geometry continues eastward, but just off the eastern edge of fig. 3, around $300 \mathrm{~km}$, a prominent northern strand develops (fig. 2). We infer that the Xorxol geometric segment is at least $200 \mathrm{~km}$ long and remarkably straight (Washburn, 2001).

\section{Xorxol Segment paleoseismic investigation}

\section{Overview}

Seismogenic properties such as fault straightness and maximum displacement during the last earthquakes at specific sites along the central ATF were presented above and in Washburn et al. (2001) and Washburn (2001). The next steps in characterizing the seismogenic behavior of the Central Altyn Tagh Fault are determinations of recent earthquake timing and estimates of magnitude. In order to establish the timing of past earthquakes, we made $\sim 10$ exca-

Table I. ${ }^{14} \mathrm{C}$ data for the Camel paleoseismic site. All analyses are standard AMS dates from CAMS facility at LLNL. $\delta^{13} \mathrm{C}$ values are the assumed values according to Stuiver and Polach (1977). Values measured for the material itself are given with a single decimal place. The quoted age is in ${ }^{14} \mathrm{C}$ years using the Libby half life of 5568 years and following the conventions of Stuiver and Polach (1977). ${ }^{14} \mathrm{C}$ concentration is given as fraction modern, $\mathrm{D}^{14} \mathrm{C}$, and conventional ${ }^{14} \mathrm{C}$ age.

\begin{tabular}{cccccccccc}
\hline \hline $\begin{array}{c}\text { Field sample } \\
\text { name }\end{array}$ & CAMS \# & $\delta^{13} \mathrm{C}$ & $\begin{array}{c}\text { Fraction } \\
\text { modern }\end{array}$ & \pm & $\mathrm{D}^{14} \mathrm{C}$ & \pm & ${ }^{14} \mathrm{C}$ age & \pm & $\begin{array}{c}2 \sigma \text { calibrated } \\
\text { age }(*) \text { (cal A.D.) }\end{array}$ \\
\hline C 1 & 69687 & -25 & 0.8923 & 0.0035 & -107.7 & 3.5 & 920 & 40 & $1024-1209$ \\
C 7 & 69688 & -25 & 0.9592 & 0.005 & -40.8 & 5 & 330 & 50 & $1456-1650$ \\
C 8 & 69689 & -25 & 0.9855 & 0.0048 & -14.5 & 4.8 & 120 & 40 & $1676-1939$ \\
C 10A & 69690 & -25 & 0.7921 & 0.0034 & -207.9 & 3.4 & 1870 & 40 & $60-240$ \\
C 16 & 69691 & -25 & 0.8912 & 0.0043 & -108.8 & 4.3 & 930 & 40 & $1022-1191$ \\
C 20 & 69692 & -25 & 0.8639 & 0.0047 & -136.1 & 4.7 & 1180 & 50 & $717-980$ \\
C 22 & 69693 & -25 & 0.9803 & 0.0039 & -19.7 & 3.9 & 160 & 40 & $1662-1950$ \\
C 24 & 69694 & -25 & 0.7376 & 0.0042 & -262.4 & 4.2 & 2440 & 50 & $762-403$ B.C. \\
C 25 & 69695 & -25 & 0.9874 & 0.0039 & -12.6 & 3.9 & 100 & 40 & $1678-1937$ \\
C 26 & 69696 & -25 & 0.8929 & 0.0045 & -107.1 & 4.5 & 910 & 50 & $1022-1221$ \\
C 32 & 69697 & -25 & 0.6212 & 0.003 & -378.8 & 3 & 3820 & 40 & $2404-2140$ B.C. \\
C 45 & 69698 & -25 & 0.5745 & 0.0027 & -425.5 & 2.7 & 4450 & 40 & $3337-2924$ B.C. \\
SL rabbit & 69699 & -25 & 1.1245 & 0.0054 & 124.5 & 5.4 & $>$ Modern & & $>1950$ \\
SL camel & 69700 & -25 & 1.2074 & 0.0058 & 207.4 & 5.8 & $>$ Modern & $>1950$ \\
SL stick & 69701 & -25 & 1.1898 & 0.0052 & 189.8 & 5.2 & $>$ Modern & & $>1950$ \\
\hline
\end{tabular}

(*) Determined with Calib 4.2 (Stuiver et al., 1998). Does not include curve intercepts comprising < $2 \%$ of the probability distribution. 


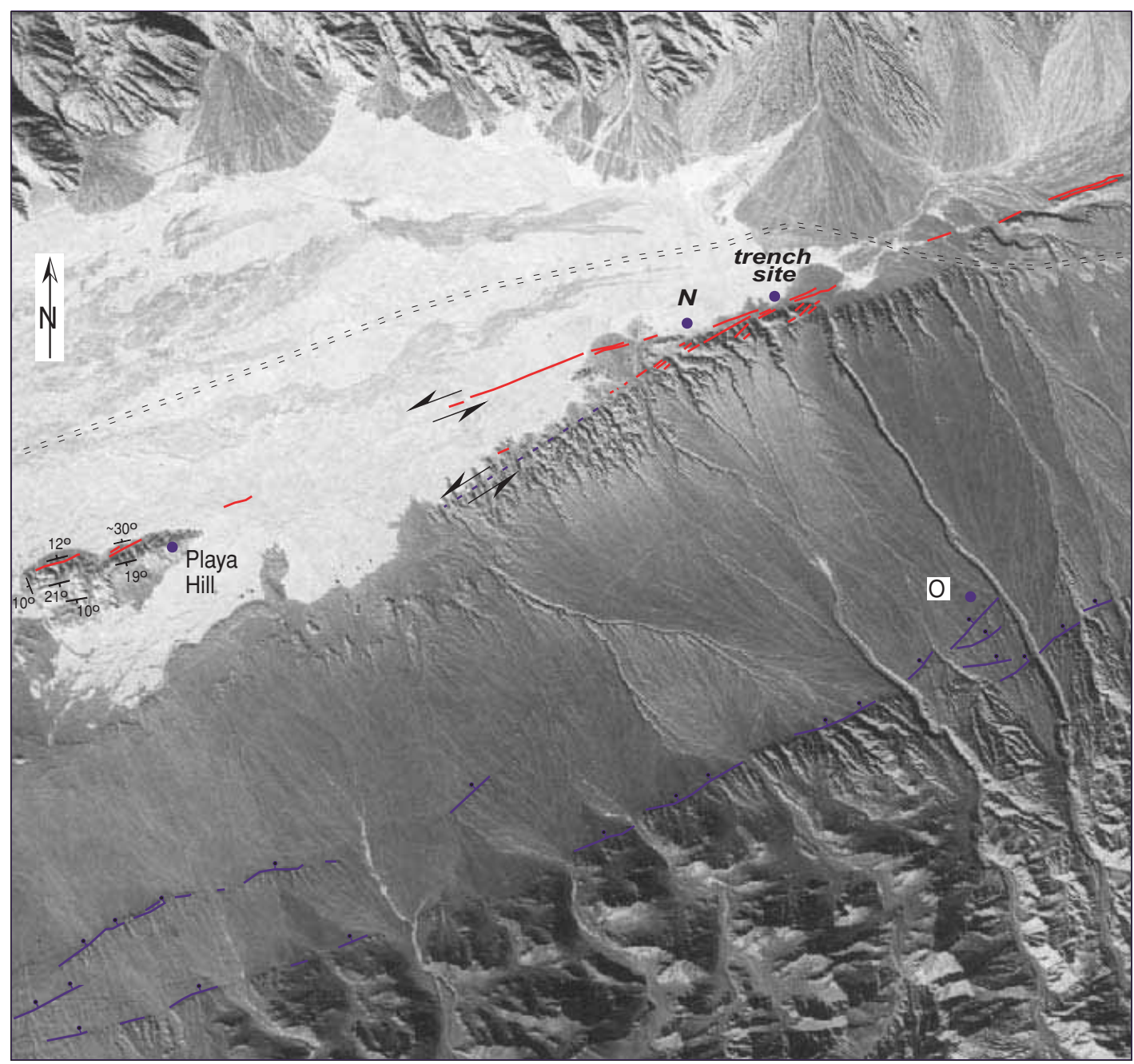

195

197.5

Along-fault distance $(\mathrm{km})$

200

\section{Explanation}

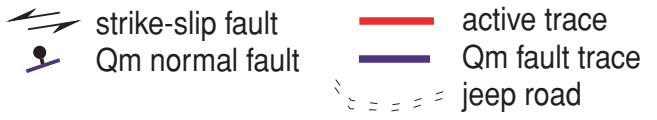

Fig. 4. Fault trace map showing main strike-slip rupture cutting Playa Hill, the eastern end of the playa, small alluvial fans at the base of north facing escarpment, and the Camel paleoseismic site. Note the $058^{\circ}$-striking secondary strikeslip fault, which intersects the main trace at $(\mathrm{N})$ and dies out within $\sim 2 \mathrm{~km}$ along strike to the southwest. The Qm normal faults located along the piedmont and range front to the south have 1-8 $\mathrm{m}$ high degraded scarps indicating they have not ruptured recently. The only exception is a slightly sharper scarp seen at $(\mathrm{O})$. However its more distal position may explain this morphologic difference. Base image is a rectified CORONA photograph. See fig. 3 for location of this site. 
vations somewhat evenly spaced along the field area (fig. 3). Interpretations of logs of these excavations are presented in Washburn (2001). In addition, early results from 1998 and 1999 excavations are presented in Washburn et al. (2001). Here, we present observations and inferences from the Camel site where the record of repeated ground rupture was best preserved (figs. 3 and 5). All of the ${ }^{14} \mathrm{C}$ data are presented in table I.

\subsection{Camel site setting}

The Camel excavation has an understandable relationship with neighboring faults, reveals a clear stratigraphy, and preserves abundant organic material. This site yields the most robust timing constraints for recent earthquakes of all our paleoseismic sites. A secondary $058^{\circ}$ striking, strike-slip fault intersects the active trace one kilometer west of the Camel trench site and normal scarps cut the Qm piedmont 2.5 $\mathrm{km}$ south of this site (fig. 4). These secondary structures could allow for an incomplete earthquake record in excavations across the active trace. Fortunately, degraded surface rupture implies that the $058^{\circ}$ strands probably did not rupture during the last earthquake and the normal faults also probably have not ruptured during the last several earthquakes. Additionally, it is unlikely that the $058^{\circ}$ system would rupture independently because of its close proximity to the active trace. In support of this assumption, the portion closest to the active trace has sharper scarps (shown in red on fig. 4) and preserves geomorphic offsets (moderately reliable $3.5 \mathrm{~m}$ ), while farther west there is no evidence for recent surface rupture. Therefore, we hypothesize that the last earthquake on the main trace activated the only the easternmost part of the $058^{\circ}$ fault. Furthermore, because the site emphasizes earthquake timing, a broader rupture zone should provide better and redundant constraints than a narrow one. See Washburn (2001) for more detailed geometric observations and further
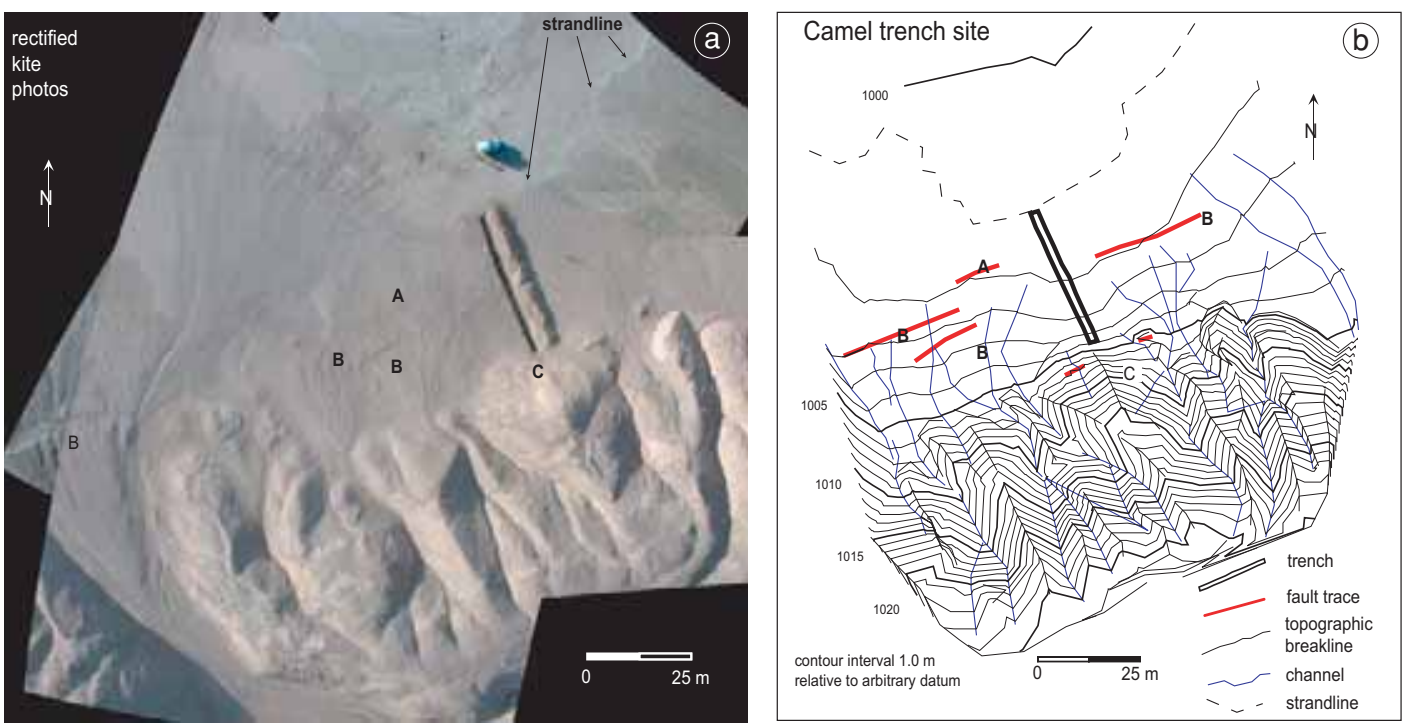

Fig. 5a,b. a) Rectified kite aerial photograph mosaic showing the geomorphic setting and geometry of surface rupture traces at the Camel trench site. Note the playa strandline at the north end of the trench, small dunes just south of the strandline on the east side of the trench, Neogene hills at the southern end of the trench, and alluvial fans at the base of these hills. b) Topographic map quantifying the landforms at this site. The letters (A, B, C) on both figures identify corresponding fault traces discussed in the text. 
review of secondary structures at the Camel site.

Four geomorphic processes interact to create an environment that is conducive to paleoseismology (fig. 5a,b). On the northeast side of the trench, small dunes are visible. They create distinctive cross bedded deposits comprised of well rounded, medium to coarse-grained sand (fig. 9). Small alluvial fans on the west side of the trench deposit muddy sand and fine gravels units seen in the trench. To the south, low hills of indurated Neogene silts comprise the «basement» units exposed in the southern part of the trench. The playa edge contributes fine silt and muddy strata to the northern end of the trench and introduces organic material at regular intervals. Individual pieces of wood and dung are sporadically exposed throughout the trench strata. In addition, playa strandlines are also preserved in numerous places in the strata.

A modern strandline is seen in fig. 5a,b; it formed by shallow inundation of the playa and subsequent rafting of organic material towards the leeward end of the playa. Regular seasonal winds blow to the east and have subsequently concentrated woody material, flower parts, camel dung, and rabbit dung in $<1 \mathrm{~m}$ wide by $\sim 5$ $\mathrm{cm}$ high by $10 \mathrm{~s}$ of $\mathrm{m}$ long deposits ringing the playa edge. Radiocarbon dating of the modern strandline allows us to evaluate the residence time of these deposits and therefore possibility for detrital ages from the trench strandlines (table I). Although 2 unconformities were identified within the trench, their planar contact implies that erosion was not significant. Furthermore, the presence of strandlines at different stratigraphic levels in the trench generally implies that nearly continual deposition has been occurring at this site. This is key to preservation of a complete earthquake record. The intermixing of these various sedimentary deposits results in distinctive, interpretable, and datable stratigraphy at the Camel trench, which in turn allows us to determine earthquake timing at this site (figs. 6, 7a,b and 9).

The active trace near the trench sites consists of two prominent fault traces, $12-15 \mathrm{~m}$ apart that have been almost entirely degraded in places (figs. 4 and 5a,b). A possible third trace breaks along the Neogene hill front. We exca- vated a $34 \mathrm{~m}$ long trench across all three of these traces to minimize the potential for missing an event. The trench stratigraphy closely corresponds with the geomorphic processes at this site (figs. 6, 7a,b and 9). Playa and dune sediments thicken toward the northern end of the trench, while coarser sand and gravel (alluvial fan) units and Neogene bedrock dominate the southern end. We identified 6 fault zones with recurrent disruption of the stratigraphy and number these starting with fault zone 1 in the north end of the trench. We also number stratigraphic units upward and show their contact relationships in fig. 7a,b. Projection of preserved portions of active trace indicate that the northern trace (A on fig. 5a,b) corresponds with fault zones 1 and 2 and the southern trace (B on fig. 5a,b) forms fault zones 3 and 4 (fig. 9).

\subsection{Camel Most Recent Earthquake (MRE)}

Faults in zones 1-4 cut units 100 through 130 and sometimes 140, however fractures in fault zones 1 and 2 cut higher units (fig. 9). These fractures show no offsets across them and the often show downward terminations at medial stratigraphic levels. These characteristics and proximity to the playa show the fractures are probably desiccation-mud cracks and non-tectonic.

From fault zones 1 to 4 , the silts comprising unit 140 grade to coarse sand and fine gravel and erode the top of dune unit 130 (figs. $7 \mathrm{a}, \mathrm{b}$ and 9). On the east wall, fault zone 1 shows faults terminating in the middle of unit 140, while zone 2 shows faults capped by unit 140. In portions of fault zones 3 and 4, unit 140 is missing. The west wall shows the same general trend of thinning and eventual disappearance of unit 140 south of fault zone 4 . We interpret unit 140 as a time transgressive unit that was deposited before and after the last earthquake based on these cross-cutting relationships and because the faults seen in zones 1-4 ruptured the surface based on the fault traces on either side of the trench. Unit 140 is probably a sheet flow deposit coming from runoff-driven sediment transport on the small alluvial fan. The base of 150 is the event horizon for the last earthquake in these fault zones. 


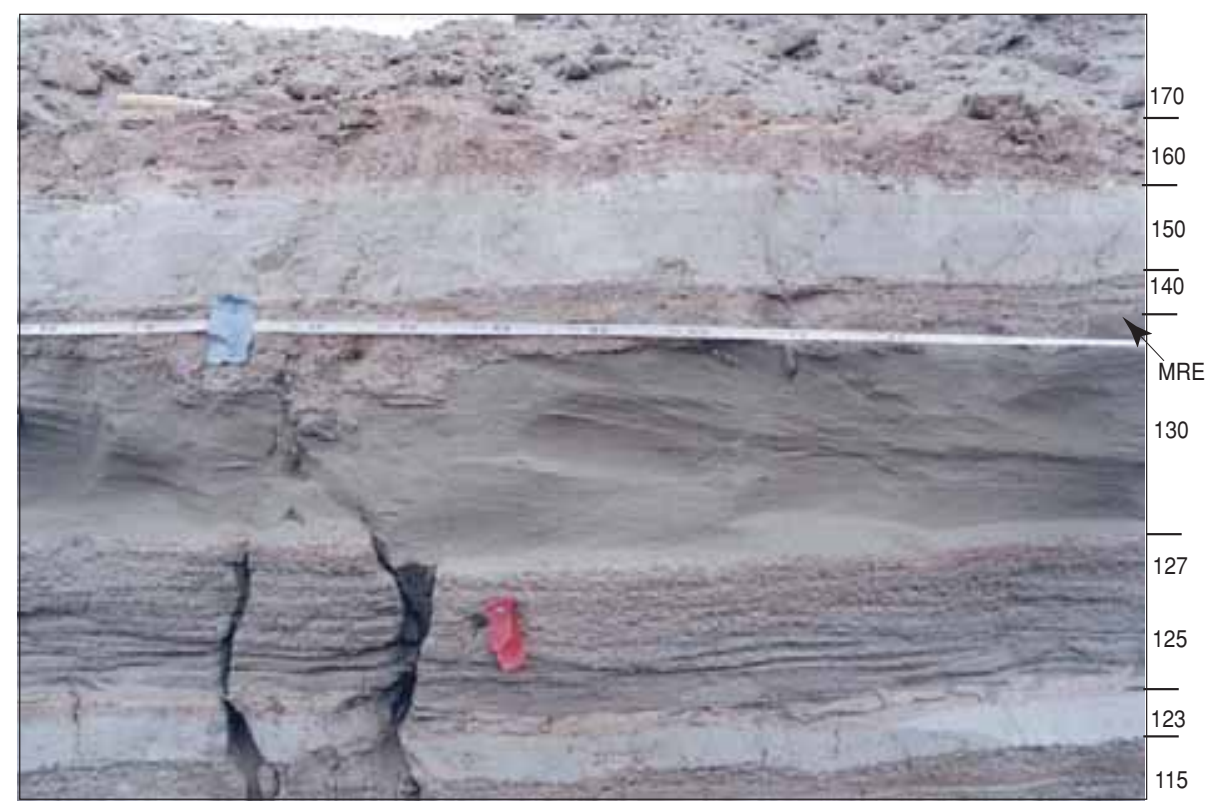

Fig. 6. Photograph of fault zone 1 on east wall of Camel trench (fig. 9). Note the metric tape measure on the trench wall for scale. Photograph shows, from top to bottom, units 170, 160, 150, 140, 130 (thick crossbedded sand), 127, 125, 123, and 115. Note that the faults have upward terminations between the top of unit 130 and the base of unit 150. This relationship shows rupture resulting from the last earthquake at the Camel site.

On the east wall of zone 5, a single fault surface cuts unit 130 and is covered by unit 160 (fig. 9). Unit 150 pinched out north of this point, so these cross cutting relationships are similar to those in fault zones 1-4. On the west side, unit 123 is disrupted by the same fault, however a $<3 \mathrm{~cm}$ wide fissure implies higher rupture through unit 127 . In fault zone 6 , a single fault cuts to the same level (unit 127). South of the zone 6, numerous faults cut Neogene basement and strongly indurated Quaternary gravels. Compared to fault zones 1-4, the smaller fault zones and amount of disruption suggest that fault zones 5 and 6 slipped only a small amount and may be reactivated older principal rupture zones. The consistent level of upward fault terminations indicates that the base of 150 is the event horizon for the last earthquake. Units 130 and 140 represent the ground surface at this time. The southern end of the trench has thinner units and thus does not record the surface ruptures as well as the lower gradient northern end.
Note the gently convex warp in the strata on east wall of fault zone 3. This is apparently a buried moletrack formed during the last earthquake and subsequent erosion beveled the top off. Below it gently folded strata are strata deformed prior to the last earthquake.

Erosion over the top of fault zone 6 makes correlation of fracture events there difficult. However, fractures do terminate at the base of a unit correlated to 140 in the northern portion of the trench.

\subsection{Camel penultimate earthquake}

Different levels of induration and an irregular contact sometimes showing centimeter deep rills identify an unconformity between units 105 and 100. The west side of fault zone 2 shows folded and faulted strata of unit 100 overlain by undeformed silts and sands of unit 105. This relationship is also seen on the other side of this fault zone and indicates the penultimate rupture 


$\begin{array}{ll}\text { RADIOCARBON SAMPLES } & \mathrm{O} \text { older than penultimate event } \\ \diamond \text { younger than MRE } & 115 \text { unit number } \\ \mathrm{X} \text { older than MRE/younger than pen. } & \text { uncf unconformity }\end{array}$

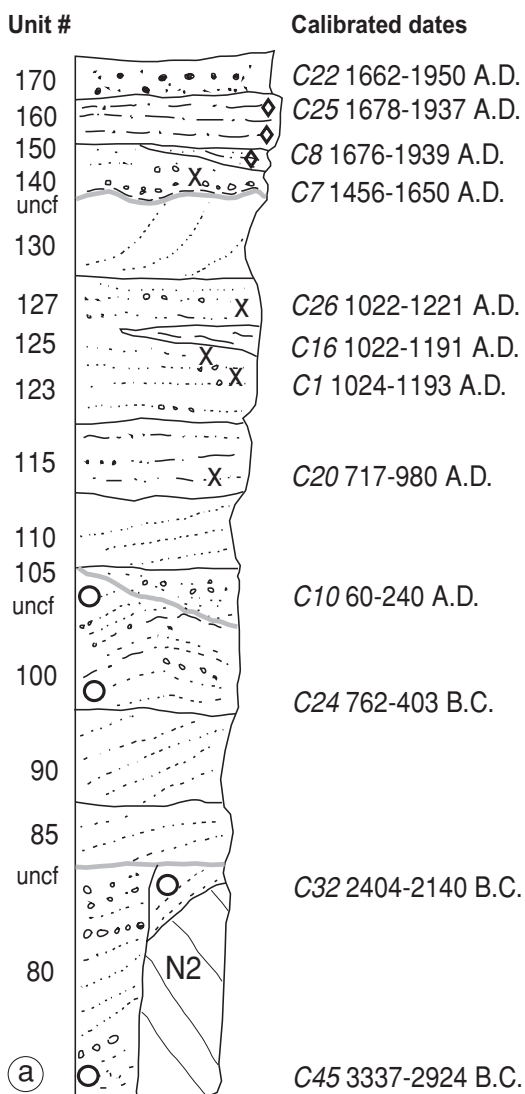

Radiocarbon dates and calibrated curves from OxCal 3.5

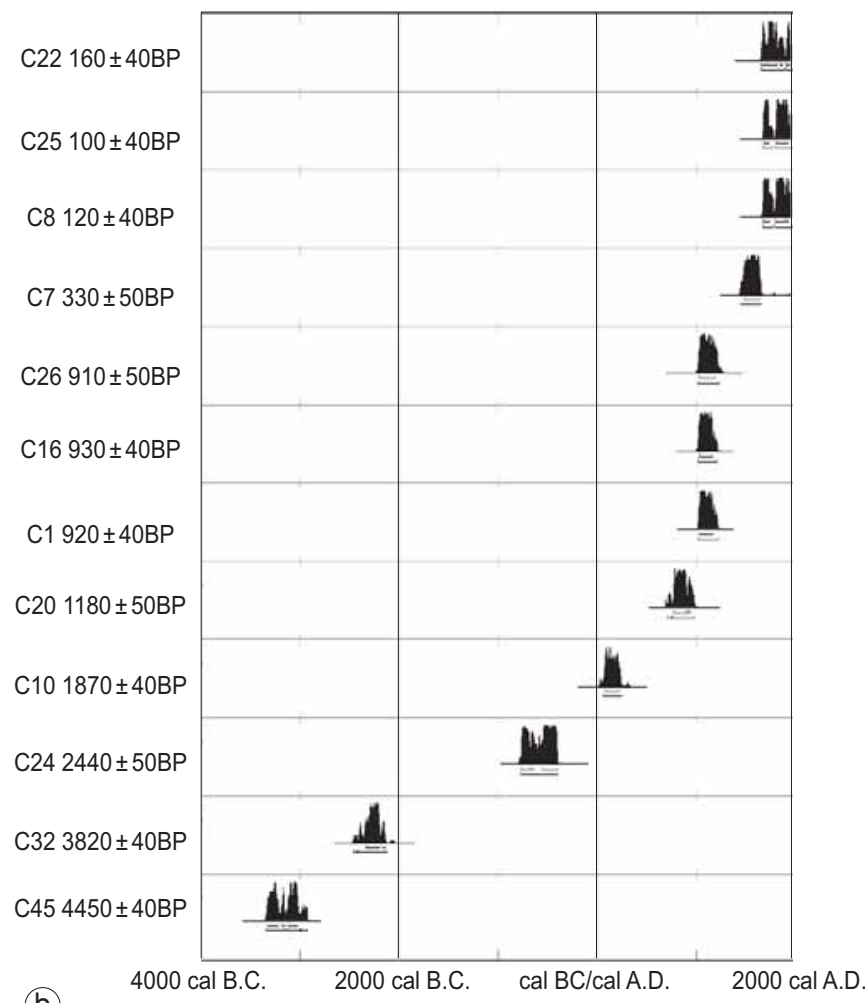

Fig. 7a,b. a) Stratigraphic column of Camel trench showing relative unit thickness, unit number, major unconformities, and stratigraphic location of radiocarbon samples. Diamonds show dates above the MRE, Xs show dates older than the MRE, and Os are older than the penultimate event. Weak evidence in the trench near fault zone 2 suggests an event at the level of unit 125 . b) Probability distributions for calendar dates determined from the radiocarbon age for each sample using OxCal v3.5 (Ramsey, 2000).

(fig. 9). Additional evidence for the penultimate event is seen in heavily deformed strata overlain by less deformed strata in fault zone 3 . Both sides of fault zone 4 show upward fracture terminations and increased local erosion at the 100-105 unit contact. Fault zone 5 shows a clear north side up sense of offset below the unconformity. Therefore unit 100 is the youngest unit cut by the penultimate event and the unconformity is the penultimate event horizon. As noted above, the MRE and the penultimate events produced local highs (moletracks) that are especially well manifest on the east side of fault zone 3, but also evident in fault zones 4 and 5 . Each time they formed, they were erosionally beveled. 


\subsection{Other possible earthquakes in the Camel trench}

There is limited evidence for a possible event occurring before the MRE, but after the penultimate event. Two $50^{\circ}$ south dipping fault traces apparently terminate in unit 125 and 130 on the east wall of fault zone 2 (fig. 9). The die out of the tip in unit 130 is most likely due to dilatation of the sand unit. The base of unit 127 could be a rupture horizon that lies between the MRE and penultimate event horizons. However, we do not see similar relationships on the west wall. There, the two faults have tips within unit 130; therefore it is likely that the tipline of the faults plunge eastward. A fault trace splays into three strands that are apparently overlain by continuous bedding of unit 130 on the east wall of fault zone 3 (fig. 9). This potential rupture horizon could also represent an intermediate earthquake. The corresponding fault on the west wall ruptures to a higher level, supporting the idea of upward die out or plunging tip line (fig. 9). We also see a fault trace that ruptures to an intermediate level in the southern part of fault zone 4. On the east wall this fault is capped by unit 110 , but breaks to the top of 110 on the west wall (fig. 9). This situation is similar to fault zone 3 and could also represent an intermediate event. However, the different rupture levels could also result from a plunging tip line of an MRE fault trace.

If the intermediate level terminations seen in fault zones 2, 3 and 4 represent an intermediate event, then it produced only small amounts of disruption of the trench strata. In contrast, the MRE and penultimate events produced intense disruption of the strata along the entire $>30 \mathrm{~m}$ length of the trench. Therefore, the limited deformation, seen as only $\sim 3$ faults, indicate that this intermediate event was different and had lower magnitude than the MRE and penultimate events. We favor an interpretation of upward die out and/or plunging tip line of MRE fractures because the faulting relationships are not the same on both trench walls and the much smaller degree of deformation compared to ruptures seen in other trenches in the study area.
More substantial evidence for a pre-penultimate event is seen $\sim 1 \mathrm{~m}$ north of and in the bottom of fault zone 5. Here, faulted and tilted strata are overlain by flat lying bedded sand and fine gravel of unit 85 . These relationships are suggestive of an earthquake before the penultimate event, however the trench was not deep enough to confirm this event.

Fault zone 6 preserves evidence of the failure of large blocks of the local Neogene basement indurated silts into mostly eolian sands. The blocks are strongly fractured and in combination with the windblown sands represent a slightly different environment than the eolian sand and alluvial fan muddy sands and gravels to the north, further making correlation of events with the rest of the trench difficult.

\subsection{Camel ${ }^{14} \mathrm{C}$ dating}

We collected 57 samples of organic material from the trench and dated 12, as well as 3 from a modern strandline. Because much of the organic material in the Camel trench was represented in modern strandlines, and often deposited as strandlines, we dated the modern ones to assess their ability to define the depositional age. The 3 strandline samples are all modern. Thus, the ${ }^{14} \mathrm{C}$ dates in the trench probably do not include a significant pre-depositional age. The ${ }^{14} \mathrm{C}$ data are presented in table I and the probability distributions from calibrations using OxCal (Ramsey, 2000) are shown in fig. 7a,b.

An 8 by 5 by $3 \mathrm{~mm}$ piece of wood with intact bark (C8) from unit 150 provides an upper bound of 1676-1939 cal A.D., while a rabbit dropping (C7) yields a lower bound of 1456-1650, for the last earthquake in this area. Likewise, an elongate rabbit dropping (C20) places an upper bounds of 766-980 cal A.D. and $\sim 10$ small pieces of woody debris were mixed (C10) to provide a lower bounds of 60-240 cal A.D. for the penultimate event. The oldest strata exposed in the trench are between 3337-2924 cal B.C. based on a radiocarbon date from piece of wood (C45).

Because of the complete stratigraphic agreement within all 12 samples, we used OxCal 
to refine the constraints on event timing (Ramsey, 2000). This program uses stratigraphic ordering constraints to eliminate overlapping age probabilities, which refines our earthquake timing brackets. We used 1950 A.D. as an upper event boundary because the world wide seismic network was able to detect moderate sized earthquakes by this time. OxCal is most useful for samples that are closely spaced stratigraphically and yield similar radiocarbon ages.

C22 is located near the top of unit 160 while $\mathrm{C} 25$ in the lower part of this unit and C8 is located in unit 150 . These samples all yield similar calendar ages (table I), however their stratigraphic position allows $\mathrm{OxCal}$ to cut off overlapping portions of their probability calendar age distributions. This is useful because this part of the calibration curve results in a wide age range (e.g., 1676-1939 for C8).
After running OxCal, C8 yields a narrow upper bound of 1676-1775 for the Camel MRE. The lower bound of 1456-1650 cal. A.D. remains unchanged because the next lowest sample (C26 1022-1221 cal A.D.) is much older and therefore probability distributions do not overlap. The lower bound on the penultimate earthquake is also unchanged for the same reason. Above the penultimate event horizon, unit 125 contains 2 radiocarbon samples, however they are spaced over an $8 \mathrm{~m}$ horizontal distance and sit at the approximate same stratigraphic level. Therefore we cannot apply ordering constraints to these samples, although C26 in unit 127 does shift their age distributions $\sim 30$ years older.

Figure $8 \mathrm{a}, \mathrm{b}$ shows the earthquake timing constraints at a number of sites along the central ATF. The ages displayed in fig. 8a are calibrated but otherwise not refined with strati-

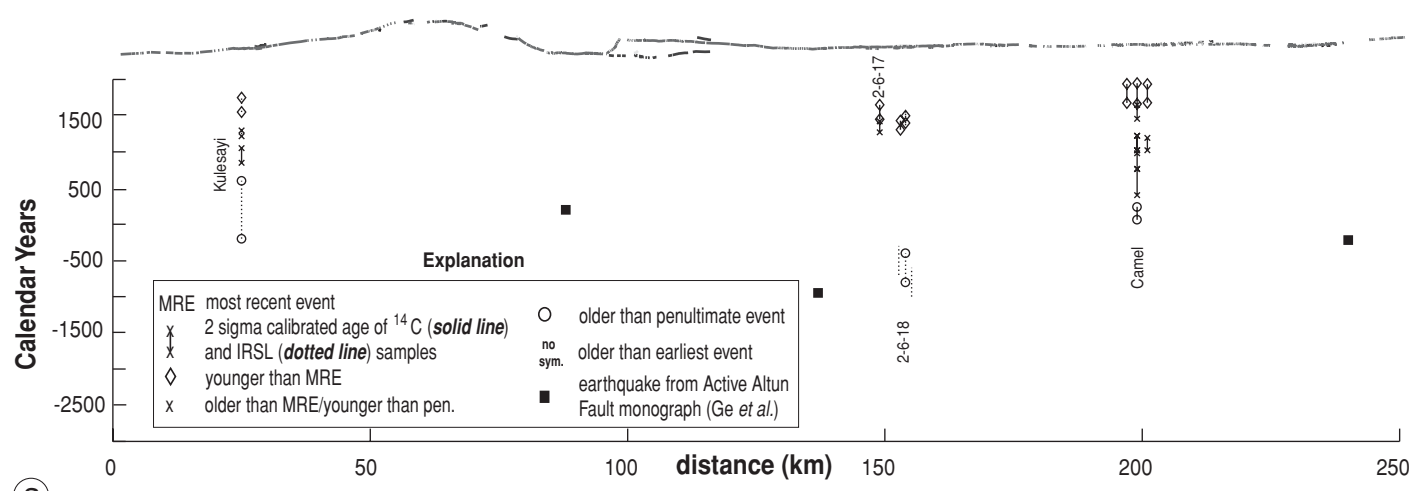

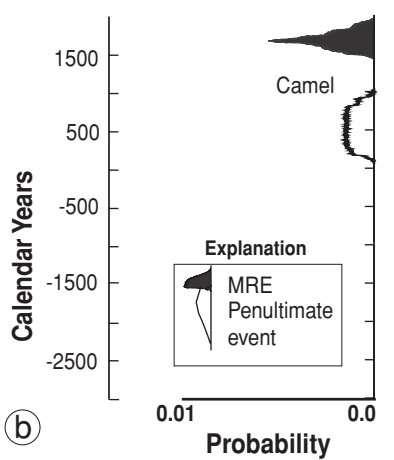

Fig. 8a,b. a) Earthquake timing constraints from stratigraphic relationships and ${ }^{14} \mathrm{C}$ and Infrared Stimulated Luminescence (IRSL) samples (from this study and Washburn et al., 2001). Note the active trace map above plot A for reference. These are the calibrated ages without $\mathrm{OxCal}$ or other refinements from stratigraphic ordering. b) Monte Carlo probability plot for the Camel paleoseismic site earthquake timing data (Hilley and Young, 2003). The area under the curves represents the probability distribution of the age of past earthquakes. Sharper peaks represent well-constrained events and show the refinement of the Camel event ages. 


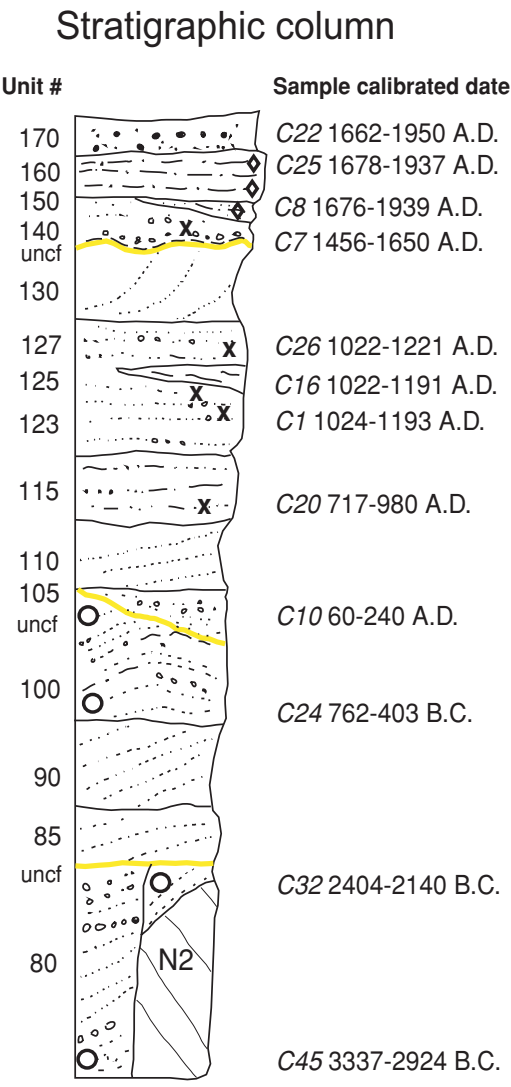

\section{Key}

Radiocarbon samples

$\diamond \quad$ younger than MRE

$\mathbf{X}$ older than MRE/younger than pen.

older than penultimate event

uncf unconformity

115 unit number

C45 3337-2924 B.C.

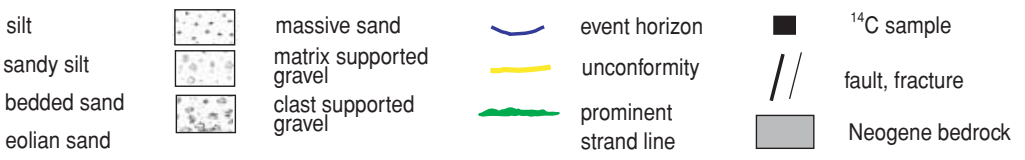

Fig. 9. Trench logs for the Camel paleoseismic site at $198 \mathrm{~km}$. Most faults terminate at the upper blue line, the event horizon for the last earthquake at this site. The penultimate earthquake is identified by upward fault terminations and folded bedding overlain by continuous strata, which is marked by the lower blue line. This penultimate event horizon coincides with a small unconformity (yellow line) identified by different levels of induration and an irregular contact with $\mathrm{cm}$ deep rills in places. Stratigraphic column of Camel trench at lower left shows relative unit thickness, unit number, major unconformities, and stratigraphic location of radiocarbon samples. See discussion in text for further interpretation and timing constraints on earthquakes seen in this trench. 


\section{sourt}

taut zone 6

tat taut zone $6 \quad$ tane 5

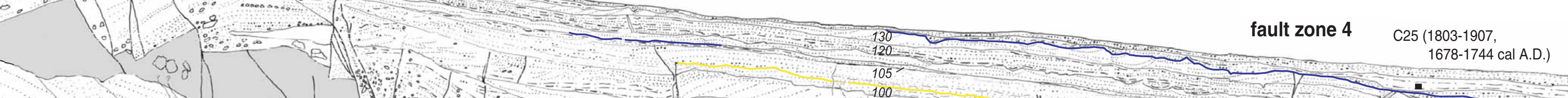

fault zone 3

fault zone 2

fault zone 1 Unt trumbers

west wall

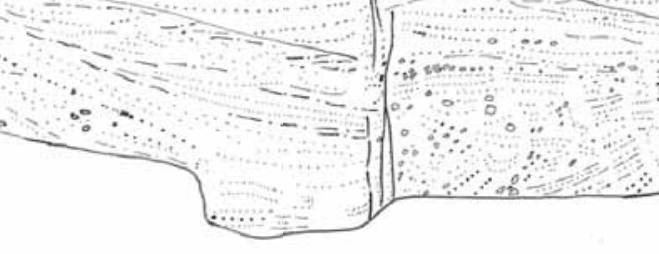
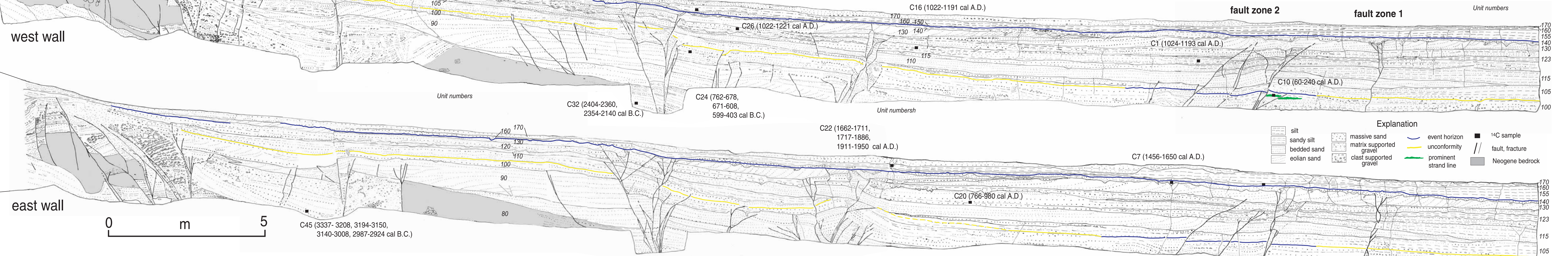

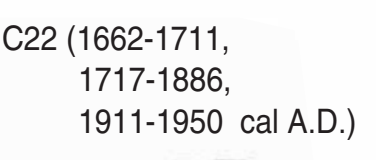

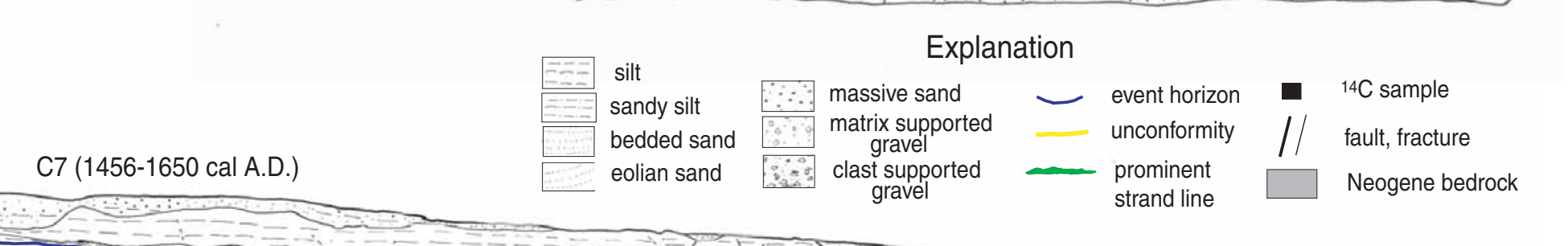

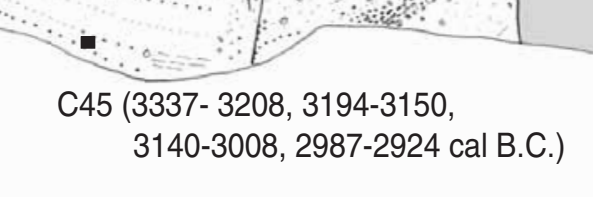
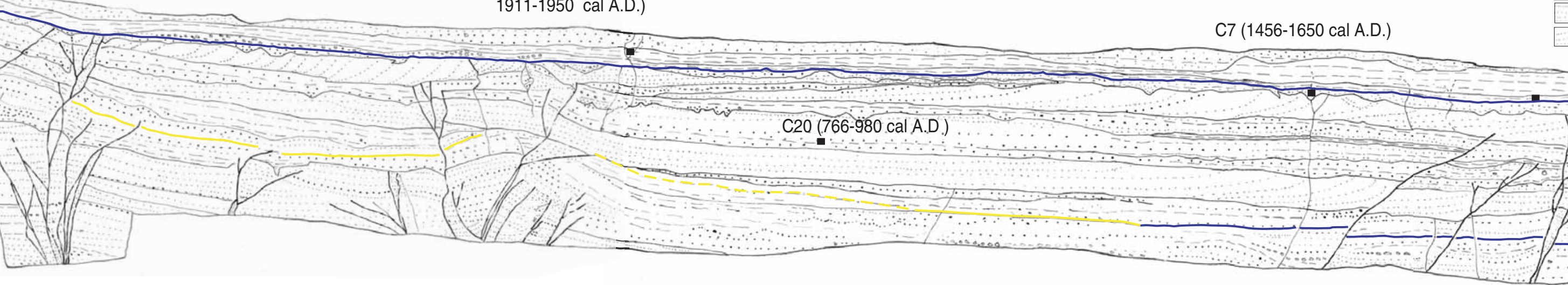
graphic ordering constraints using OxCal. Hilley and Young (2003) have developed a ${ }^{14} \mathrm{C}$ age refinement method that is similar to $\mathrm{OxCal}$ and produces probability curves for events with a Monte Carlo-based analysis of ${ }^{14} \mathrm{C}$ age calibration and stratigraphic ordering. We show the probability curves for the last two well-defined Camel events determined using the Hilley and Young (2003) method in fig. 8b.

\section{Discussion}

\subsection{Earthquake ruptures along the Central Altyn Tagh Fault}

Correlation of earthquakes between paleoseismic sites can lead to misinterpretation because not all strands in wide fault zones may be activated during an earthquake. We have eliminated most of the potential for this scenario by thorough evaluation of paleoseismic sites and excavation across only the sharpest, most active traces. However, «dogtail» rupture terminations in the middle of geometric segments and may not rupture through all excavations in question (e.g., Ward, 1997). Therefore trenches showing overlapping geochronologic earthquake constraints that are only $10 \mathrm{~s}$ of kilometers apart may not record the same earthquake. We therefore utilize other observations to help clarify the rupture history.

We know the peak surface displacement at a given site from the offset data (Washburn, 2001; Washburn et al., 2001) and we have constrained earthquake timing at a number of paleoseismic sites. With these data, we can determine crude recurrence intervals, because we have only 1-3 events in each trench. We can also make magnitude estimates using the displacement data. Better estimates of moment magnitude $\left(M_{w}\right)$ can be achieved by using Surface Rupture Length (SRL) (Wells and Coppersmith, 1994). We estimate surface rupture length by utilizing geometric constraints, offset distribution, surface rupture morphology, timing constraints from the trench sites.

Figure 8a,b shows that the last earthquake at Kulesayi, 2-6-17, 2-6-18, and the Camel site all occurred at the approximate same time, be- tween 1215-1775 cal A.D. (data from Washburn et al., 2001, and this paper). However, it is unlikely that one large earthquake ruptured the entire field area between 1215-1775 cal A.D. In such a case, the MRE would have jumped two geometric boundaries and ruptured from the Kulesayi trench $(23 \mathrm{~km})$ to at least the Camel trench $(199 \mathrm{~km})$ and likely farther based on the offset distribution and sharp surface rup-

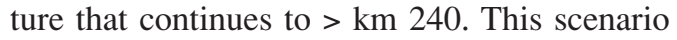
yields a SRL of $>220 \mathrm{~km}$ and $M_{w}>7.8$. However, consideration of details of the age control from the excavations and the geometric boundaries makes it unlikely, and the relatively high slip implied $(\sim 10 \mathrm{~m})$ is not consistent with our inferred offset distribution (maximum offset $\sim 7 \mathrm{~m}$; Washburn, 2001; Washburn et al., 2001).

It is possible that the $4 \mathrm{~km}$ Pingding left step barred rupture. The Arkateng Restraining Bend and associated complexities around Dayang Shan are also potential rupture barriers fig. 3 . Furthermore, the discontinuous and degraded surface rupture around these boundaries argues for smaller earthquakes that did not rupture the whole field area. Therefore we separate Wuzhunxiao and Pingding events from Xorxol events based on surface rupture morphology and geometric boundaries. Consequently, the last earthquake at Kulesayi occurred between 1215 and 1750 A.D. and may have produced the 3-5 m offsets on the west side of Lake Wuzhunxiao (fig. 8a,b; Washburn et al., 2001). Along the Xorxol Segment, the timing constraints imply that the last earthquake ruptured its western portion before the eastern portion broke. The last earthquake in the west ruptur ed 1270 and 1430 cal A.D. (from Bitter Sea published results of Washburn et al., 2001; fig. $8 \mathrm{a}, \mathrm{b})$. This rupture may go from western end of the Xorxol Segment to around the Bitter Sea $(\sim 50 \mathrm{~km}$ SRL) with peak displacement of $\sim 7$ m (Washburn, 2001; Washburn et al., 2001). The younger Camel MRE occurred between 1456 and 1775 cal A.D. (fig. 8a,b). It ruptured from somewhere east of the Bitter Sea through the Camel trench and likely farther based on the rounded and semi continuous moletracks between $247 \mathrm{~km}$ to the edge of the study area (268 $\mathrm{km}$, fig. 3). The degraded nature of the surface rupture suggests that this reach is either the 
eastern terminus of the Xorxol MRE or that erosion rates, which are detectably higher in this area, led to the more degraded surface rupture. Higher erosion rates are plausible because of the position of the Eastern Xorxol Valley relative to the «mouth» of the Tarim Basin only $7 \mathrm{~km}$ north of the playa at $265 \mathrm{~km}$ on fig. 3. The mouth allows more frequent storms and intense daily winds to blow through Eastern Xorxol Valley and more animal access and potential degradation.

In summary, the last earthquakes along the Central Altyn Tagh Fault: 1) occurred between 1215 and 1775 cal A.D.; 2) had maximum displacement of $\sim 5 \mathrm{~m}$ on the Wuzhunxiao and Pingding segments and $7 \mathrm{~m}$ on the Xorxol Segment (Washburn, 2001; Washburn et al., 2001), and 3) had surface rupture lengths between $\sim 50$ and $>150 \mathrm{~km}$ with corresponding magnitudes of low $M_{w} 7 \mathrm{~s}$ to high $M_{w} 7 \mathrm{~s}$, respectively.

\subsection{Implications for slip rate based on the size and frequency of earthquakes in the last $3 \mathrm{kyr}$}

Although the earthquake data do not tightly constrain the surface rupture length or $M_{w}$ of the MRE, the recurrence times from trenches show good agreement. We find 2 earthquakes in the last 0.8-2.0 kyr at the Camel site, 3 events in the last 2.4-3.0 kyr at the Bitter Sea, and 2 Kulesayi events in the last 0.8-2.2 kyr (this paper; Washburn, 2001; Washburn et al., 2001). Although we have a limited number of events for robust recurrence calculations, taking averages from these data give repeat times of $0.7 \pm 0.3 \mathrm{kyr}$ for the Camel site, $0.9 \pm 0.1 \mathrm{kyr}$ for the Bitter Sea trenches, and $0.75 \pm 0.35 \mathrm{kyr}$ for the Kulesayi site. These frequencies are consistent with the 2 earthquakes in the past $3 \mathrm{kyr}$ reported by Ge et al. (1992) in the study area and are generally similar to the $800-1000$ year recurrence times estimated for the Kunlun Fault (van der Woerd et al., 1998).

Given the limited number of earthquakes in this study, we emphasize the tentative results derived from relating earthquake recurrence to slip rates. However, systematic underinterpretation or rupture location variability must be invoked for significantly higher recurrence rates or slip/event. If a large earthquake oc- curred in the near future, our recurrence rates would be maxima and any inferred slip rate would increase.

To compare these paleo-earthquake data with other findings along the ATF we cast slip rate in terms of average recurrence intervals by using 5 and $10 \mathrm{~m}$ of slip per event because these values bracket the peak offsets recorded for the MRE(s) (Washburn et al., 2001). Using: 1) 10 $\mathrm{mm} / \mathrm{yr}$ determined from repeat GPS surveys (Bendick et al., 2000; Shen et al., 2001) yields recurrence intervals of 0.5 and $1.0 \mathrm{kyr}$ for 5 and $10 \mathrm{~m}$ of slip per event, respectively; 2) $3 \mathrm{~cm} / \mathrm{yr}$ determined by large scale post glacial offsets and offset terraces and moraines in areas west of the study area (Peltzer et al. 1989; Meriaux et al., 2000) yields recurrence times of 0.2 and 0.3 kyr. Figure 10 shows a compilation of the various slip rates that have been inferred for the central ATF. Comparison of the different recurrence intervals show that the paleoearthquake data most closely agree with a $1-2 \mathrm{~cm} / \mathrm{yr}$ slip rate because we would expect to see 2-3 times the number of earthquakes in our paleoseismic investigations and the faulting and sedimentary record in them is not consistent with so many missing earthquakes.

An important issue in slip rate comparisons is the observed eastward decrease in slip rate along the ATF (fig. 10). Peltzer et al. (1989) inferred $\sim 3 \mathrm{~cm} / \mathrm{yr}$ rates in the area of $84^{\circ}-92^{\circ} \mathrm{E}$. Meriaux et al. $(1999,2000)$ determined $3 \mathrm{~cm} / \mathrm{yr}$ between $85^{\circ}$ and $89^{\circ} \mathrm{E}$ and $2-3 \mathrm{~cm} / \mathrm{yr}$ near $90^{\circ} \mathrm{E}$. Ryerson et al. (2003) report a well constrained $18 \mathrm{~mm} / \mathrm{yr}$ at the Pingding Shan $\left(90.5^{\circ} \mathrm{E}\right)$. Meriaux et al. (2003) determined a minimum of $20 \pm 3 \mathrm{~mm} / \mathrm{yr}$ at $94^{\circ} \mathrm{E}$. Ryerson et al. (2003) also report $12.5-15 \mathrm{~mm} / \mathrm{yr}$ at $95^{\circ} \mathrm{E}$. Meyer et al. (1996) concluded that slip rates east of $96^{\circ}$ were $4 \pm 2 \mathrm{~mm} / \mathrm{yr}$, consistent with decreasing slip rate along the ATF and accommodation of the slip gradient by thrusting along the south side in the Qaidam Basin (also suggested by Peltzer et al., 1989; Chen et al., 1999). Meyer et al. (1998) observed that the thrusts branch from the ATF and are thus kinematically linked; and van der Woerd et al. (2001) showed the decrease in slip rate and geometry of the fault junction at the Altyn Tagh Fault-Tanghenan Shan Thrust triple junction. 


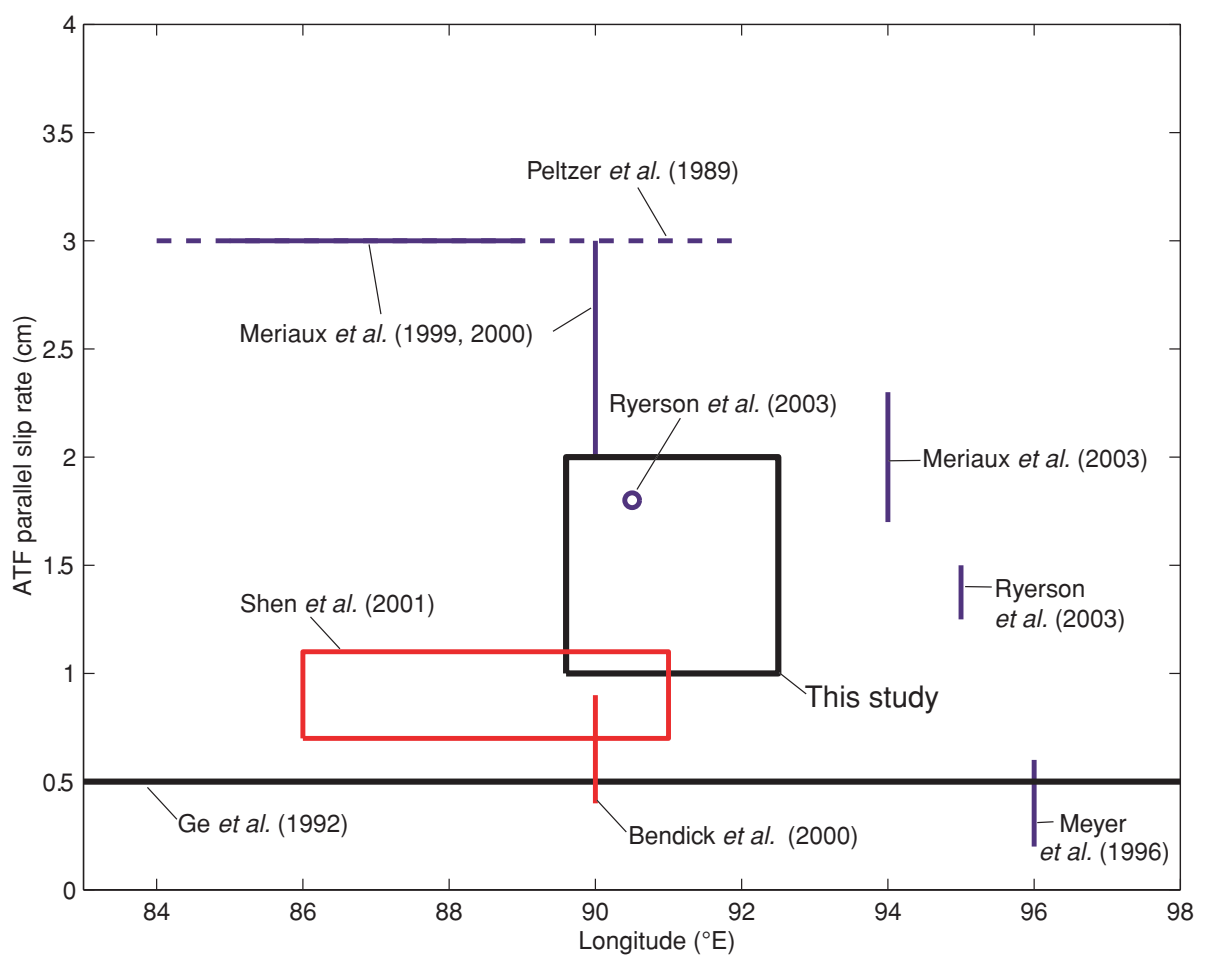

Fig. 10. Inferred Altyn Tagh Fault-parallel slip rates from long-term studies (blue), geodesy (red), and earthquake geology (black) compiled from the literature and this study. The eastward decrease in slip rate indicated by the long-term studies is consistent with the activity of numerous thrust faults splaying from and to the south of the ATF (e.g., Meyer et al., 1996, 1998; Tapponnier et al., 2001; although not consistent with the geodetic results from Shen et al., 2001). In general, the geodetic results show lower slip rates relative to the long-term studies. Our earthquake geology results span the two other methods in both the time scale of measurements (a few kyr versus decadal and $>\sim 10 \mathrm{kyr}$ ) and the resulting inferred rates.

This study covers the portion of the ATF from $89.6^{\circ} \mathrm{E}$ to $92.5^{\circ} \mathrm{E}$. It is within the area covered by the higher rates in Peltzer et al. (1989) and spans the Meriaux et al. (1999) and Ryerson et al. (2003) site near the Pingding Shan $(18 \mathrm{~mm} / \mathrm{yr})$. Our best earthquake recurrence data come from the Camel site is at about $91.75^{\circ} \mathrm{E}$, so we may begin to observe a decrease in slip and thus recurrence rate due to interaction between the ATF and the adjacent active thrusts of the Qaidam Basin (for example, note that the active northwest striking Yousha-Shan thrust fault of Chen et al. (1999) approaches the ATF near the Gobiling). Although the results of Ryerson et al. (2003) and our inferred slip rate from near the Pingding Shan overlap (fig. 10), the $20 \pm 3 \mathrm{~mm} / \mathrm{yr}$ minimum rate at $94^{\circ} \mathrm{E}$ (Meriaux et al., 2003) implies a higher earthquake recurrence rate than we inferred for the Xorxol Segment.

The geodetic investigations are not sufficiently dense to image variations in slip rate along the central ATF. Given their great breadth (100 $\mathrm{s}$ of $\mathrm{km}$ perpendicular to the ATF), near fault locking and seismic cycle variation in velocity cannot explain the slip rate discrepancy (fig. 10; Thatcher, 1990; Shen et al., 2001). Shen et al. (2001) also point out that because there is no major convergence parallel to the ATF on its south side across the Qimen Tagh 
Mountains at the southern margin of the Qaidam Basin, the slip rate along the ATF must not decrease significantly between $80^{\circ}$ and $92^{\circ} \mathrm{E}$.

One explanation for the discrepancy in recurrence times from GPS site velocities and the earthquake record and geology is that a major earthquake along the central ATF is overdue. Another intriguing explanation is that the long term loading rate along the ATF has decreased in the past $100 \mathrm{kyr}$ and strain is now accommodated by other structures in Central Asia. For example, the faults that produced four $M 8$ earthquakes in Mongolia in the past century released significant strain in an area of relatively lower inferred long term deformation rate (Baljinnyam et al., 1993). Earthquakes, such as the $1997 M_{w}$ 7.6 Manyi earthquake that ruptured $170 \mathrm{~km}$ along the Kunlun Fault (Peltzer et al., 1999) and the $2001 M_{w} 7.8$ Kokoxili earthquake (van der Woerd et al., 2002; Lin et al., 2002) may indicate that the western portion of the Kunlun Fault and other central and north Tibetan strike-slip faults may be more active than previously thought. Finally, shortening within the Qimen Tagh and other contractional structures in Northern Tibet may now accommodate a higher percentage of India-Eurasia convergence (Yin and Harrison, 2000; Cowgill, personal communication).

\section{Conclusions}

In this paper, we have characterized the fault trace geometry and paleoseismology of the Central Altyn Tagh Fault, emphasizing its $\sim 230 \mathrm{~km}$ long and remarkably straight Xorxol geometric segment. Trace geometry, timing of paleoearthquakes, and inferences of rupture magnitudes contribute to the global catalogue of strike-slip fault systems and provide information about its geodynamic role in the IndiaEurasian collision.

The trace geometry of the central ATF is dominated by the Arkateng Restraining Bend, Pingding Releasing Step, and the notably straight Xorxol Segment. The geometric boundaries are probable earthquake rupture boundaries based on surface rupture continuity, distribution of small geomorphic offsets, and histor- ical data. Major Holocene deformation along the Altyn Tagh Fault System is confined to a narrow zone less than $3 \mathrm{~km}$ wide.

The geometric boundaries and timing constraints probably preclude one large earthquake rupturing all 3 segments $(270 \mathrm{~km})$. Furthermore, multiple earthquakes with shorter rupture lengths $(\sim 50 \mathrm{~km})$ rather than complete rupture of the Xorxol Segment better explain the paleoseismic data. We found 2-3 earthquakes in the last 2-3 kyr. When coupled with typical amounts of slip per event $(5-10 \mathrm{~m})$, the recurrence times are tentatively consistent with 1-2 $\mathrm{cm} / \mathrm{yr}$ slip rates. This result favors models that consider the broader distribution of collisional deformation, rather than those with northward motion of India into Asia absorbed along a few faults bounding rigid blocks.

\section{Acknowledgements}

We thank P. Molnar, R. Bilham, P. Tapponnier, M. Hamburger, R. Bürgmann, A. Yin, S. Graham, and J. Freymueller for early reviews of this research, our colleagues at the Institute of Geomechanics in Beijing, and S. Holloway, M. Baillie, S. Selkirk, E. Catlos, C. Schrein, and S. Zhang for help in the lab, field, and the office. Constructive reviews by K. Okamura and F. Galadini and the guidance of Daniela Pantosti for Annals of Geophysics were also very helpful. R. Ryerson arranged our ${ }^{14} \mathrm{C}$ dating at Lawrence Livermore National Laboratory/University of California Center for Accelerator Mass Spectrometry where we were guided by G. Sietz, M. Caffee, J. Southon, and their colleagues. G. Hilley provided important advice on interpretation of ${ }^{14} \mathrm{C}$ data. The Northern California Earthquake Data Center (NCEDC), and the member networks of the Council of the National Seismic System (CNSS) provided the seismicity data shown in fig. 2. We are particularly grateful to An Yin for inviting us to join the project and to Eric Cowgill for introducing us to field work in Xinjiang. This work is part of a collaborative research effort supported by the U.S. National Science Foundation Continental Dynamics Program (grant EAR-9725780). 


\section{REFERENCES}

Avouac, P.J. and P. TAPPONNIER (1993): Kinematic model of active deformation in Central Asia, Geophys. Res. Lett., 20, 895-898.

Baljinnyam, I., A. Bayasgalan, B.A. Borisov, A. Cisternas, M.G. DeM'yanovich, L. GanbaAtar, V.M. Kochetov, R.A. Kurushin, P. Molnar, H. Philip and Y.Y. VASHILOV (1993): Ruptures of major earthquakes and active deformation in Mongolia and its surroundings, Geol. Soc. Am. Mem., 181, pp. 62.

Bendick, R., R. Bilham, J. Freymueller, K. Larson, G. Peltzer and G. YIN (2000): Geodetic evidence for a low slip rate on the Altyn Tagh Fault and constraints on the deformation of Asia, Nature, 404, 69-72.

Chen, W-P., C-Y. Chen and J.L. NÁBelek (1999): Presentday deformation of the Qaidam basin with implications for intra-continental tectonics, Tectonophysics, $\mathbf{3 0 5}$ $165-181$.

Cowgill, E., A. Yin, X. WANG and Q. ZHANG (2000): Is the North Altyn Fault part of a strike-slip duplex along the Altyn Tagh Fault System?, Geology, 28, 255-258.

Cowgill, E., A. Yin, J.R. Arrowsmith, W. Xiaofeng and S. ZHANG (2003): The Akato Tagh bend along the Altyn Tagh Fault, NW Tibet, 1. Cenozoic structure, smoothing by vertical-axis rotation, and the effect of topographic stresses on borderland faulting, Geol. Soc. Am. (in review).

dePolo, C.M., D. Clark, B. Slemmons and A. Ramelli (1991): Historical surface faulting in the Western Basin and Range Province, Western North America: implications for fault segmentation, J. Struct. Geol., 13, 122-136.

ENGLAND, P.C. and P. MolnaR (1997): The field of crustal velocity in Asia calculated from Quaternary rates of slip on faults, Geophys. J. Int., 130, 551-582.

FORMAN, S.L. (1999): Infrared and red stimulated luminescence dating of Late Quaternary nearshore sediments from Spitsbergen, Svalbard, Arctic, Antarct. Alpine Res., 31, 34-49.

GE, S. and 34 OTHERS (1992): Active Altun Fault Zone Monograph (State Seismological Bureau, Seismological Press, Beijing, China), 1-319.

Grant, L.B. and K. SiEH (1994): Paleoseismic evidence of clustered earthquakes on the San Andreas Fault in the Carrizo Plain, California, J. Geophys. Res., 99, 68196841

HARRIS, R.A. and S.M. DAY (1993): Dynamics and fault interaction: parallel strike-slip faults, J. Geophys. Res. 98, 4461-4472.

HARRIS, R.A. and S.M. DAY (1999): Dynamic 3D simulations of earthquakes on en échelon faults, Geophys. Res. Lett., 206, 2089-2092.

HiLley, G.E. and J.J. Young (2003): Determining even magnitude and timing from paleoseismic and geomorphic data along the Central San Andreas Fault, California, Bull. Seismol. Soc. Am. (in review).

Holt, W.E., N. Chamot-Rooke, X. Le Pichon, A.J. Haines, B. SHEN-Tu and J. ReN (2000): Velocity field in Asia inferred from Quaternary fault slip rates and Global Positioning System observations, J. Geophys. Res., 105, 19,185-19,209.
Klinger, Y., J. VAN der Woerd, P. TAPPOnNier, X.W. Xu, G. KInG, W.B. Chen, W.T. MA and D. Bowman (2003): Detailed strip map of the Kokoxili earthquake rupture $\left(M_{W} 7.8,14 / 11 / 01\right)$ from space, Geophys. Res. Abstr., 5, 08487.

KNUEPFER, P.L.K. (1989): Implications of the characteristics of end-points of historical surface fault ruptures for the nature of fault segmentation, in Fault Segmentation and Controls of Rupture Initiation and Termination, edited by D. SchwarTZ and R. SiBSon, U.S. Geol. Surv. Open-File Rep. 89-315, 193-228.

Lin, A., B. Fu, J. Guo, Q. Zeng, G. DANG, W. He and Y. ZHAO (2002): Co-seismic strike-slip and rupture length produce by the $2001 \mathrm{Ms} 8.1$ Central Kunlun earthquake, Science, 296, 2015-2017.

MÉRIAUX, A.S., P. TAPPONNIER, F.J. RYERSON, J. VAN DER Woerd, C. Lasserre, X. Xu, R. Finkel and M. CAfFeE (1999): Large-scale strain patterns, great earthquake breaks, and Late Pleistocene slip-rate along the Altyn Tagh Fault (China), European Union of Geosciences Conference Abstracts, EUG 10, Terra Abstracts, 11, p. 55.

MériauX, A.S., F.J. Ryerson, P. TAPPONNIER, J. VAN DER Woerd, R.C. Finkel, M.W. Caffee, C. Lasserre, X. XU, H. Li AND Z. XU (2000): Fast extrusion of the Tibet Plateau: a $3 \mathrm{~cm} / \mathrm{yr}, 100 \mathrm{kyr}$ slip-rate on the Altyn Tagh Fault, Eos Trans. Am. Geophys. Un., 81 (48), p. 1137.

MériauX, A.S., P. TAPPONNIER, F.J. Ryerson, X. Xu, J. Van DER Woerd, G. King, R.C. Finkel, Li Haibing, M.W. CAFFEE and X. ZHIQIN (2003): Post-glacial slip rate on the Aksay segment of the Northern Altyn Tagh Fault, derived from cosmogenic radionuclide dating of morphological offset features, Geophys. Res. Abstr., 5, 08062.

Meyer, B., P. Tapponnier, Y. Gaudemer, G. Peltzer, G. SHunMin and C. Zhitai (1996): Rate of left-lateral movement along the easternmost segment of the Altyn Tagh Fault, east of $96^{\circ} \mathrm{E}$ (China), Geophys. J. Int., 124, 29-44.

Meyer, B., P. Tapponnier, L. Bourjot, F. Métevier, Y. Gaudemer, G. Peltzer, G. Shunmin and C. Zhitai (1998): Crustal thickening in Gansu-Qinghai, lithospheric mantle subduction, and oblique, strike-slip controlled growth of the Tibet plateau, Geophys. J. Int., 135, 1 - 47 .

Molnar, P. C. Burchfiel, L. K'Uangyi and Z. ZiYun (1987): Geomorphic evidence for active faulting in the Altyn Tagh and Northern Tibet and qualitative estimates of its contribution to the convergence of India and Eurasia, Geology, 15, 249-253.

Peltzer, G., P. TAPPonNier and R. Armijo (1989): Magnitude of Late Quaternary left-lateral displacements along the north edge of Tibet, Science, 246, 1285-1289.

Peltzer, G., F. Crampé and G. King (1999): Evidence of nonlinear elasticity of the crust from the $M_{w} 7.6$ Manyi (Tibet) earthquake, Science, 286, 272-276.

RAMSEY, C.B. (2000): OxCal v3.5 software that uses stratigraphic constraints to trim calendar age probability distributions, http://www.rlaha.ox.ac.uk/oxcal/oxcal.htm.

Ryerson F.J., A-S. MériauX, P. TAPPONNIER, J. VAN DER Woerd, Xu Xiwei, Li Haibing and Xu ZhiQin (2003): Northeastwards decrease in the Late PleistoceneHolocene slip-rate and propagation of the Altyn Tagh Fault (China), Geophys. Res. Abs., 5, 08070. 
Shen, Z-K., M. WANG, Y. Li, D.D. Jackson, A. Yin, D. DONG and P. FANG (2001): Crustal deformation along the Altyn Tagh Fault System, Western China, from GPS, J. Geophys. Res., 106, 30,607-30,621.

Stuiver, M. and H.A. Polach (1977): Discussion, reporting of ${ }^{14} \mathrm{C}$ data, Radiocarbon, 19, 355-363.

StUIVER, M., P.J. REIMER and E. BARD (1998): INTCAL98 radiocarbon age calibration, $24000-0$ cal BP, Radiocarbon, 40, 1041-1081.

TAPPONNIER, P. and P. MOLNAR (1977): Active faulting and tectonics in China, J. Geophys. Res., 82, 29052930.

TAPPONNIER, P, X. ZHioin, F. Roger, B. Meyer, N. Arnaud, G. WitTlinger and Y. Jingsui (2001): Oblique stepwise rise and growth of the Tibet plateau, Science, 294, 1671-1677.

THATCHER, W. (1990): Present-day crustal movements and the mechanics of cyclic deformation, in The San Andreas Fault System, California, edited by R.E. WaLlace, USGS Prof. Paper 1515, 189-205.

VAN DER WOERD, J., F.J. RYERSON, P. TAPPONNIER, Y. Gaudemer, R. Finkel, A.S. Meriaux, M.W. Caffee, Z. GuOGUANG and H. QuNLU (1998): Holocene left-slip rate determined by cosmogenic surface dating on the Xidatan Segment of the Kunlun Fault (Qinghai, China), Geology, 26, 695-698.

van der Woerd, J., X. Xu, H. Li, P. TAPponier, B. Meyer, F.J. Ryerson, A.S. MériauX and X. ZhiQin (2001): Rapid active thrusting along the northwestern range front of the Tanghe Nan Shan (Western Gansu, China), J. Geophys. Res., 106, 30,475-30,504.

VAN DER WoERd, J., A. MÉriaUX, Y. KLINGER, F.J. Ryerson, Y. GAUDEMER and P. TAPPONNIER (2002): The 14 November 2001, $M_{w}=7.8$ Kokoxili earthquake in Nort- hern Tibet (Quinghai Province, China), Seismol. Res. Lett., 73, 125-135.

WANG, Q., P-Z. Zhang, J.T. Freymuller, R. Bilham, K.M Larson, X. Lai, X. You, Z. Niu, J. Wu, Y. Li, J. Liu, Z. YANG and Q. CHEN (2001): Present-day crustal deformation in China constrained by Global Positioning System measurements, Science, 294, 574-577.

WARD, S.N. (1997): Dogtails versus rainbows: synthetic earthquake rupture models as an aid in interpreting geological data, Bull. Seismol. Soc. Am., 87, 1422-1441.

WASHBURN, Z. (2001): Quaternary tectonics and earthquake geology of the Central Altyn Tagh Fault, Xinjiang, China: implications for tectonic process along the northern margin of Tibet, M.S. Thesis, Tempe, Arizona State University, pp. 179.

WASHBURN, Z., J.R. ARROWSMITH, S. Forman, E. COWGILL, X.F. WANG, Y. Zhang and C. Zhengle (2001): Late Holocene earthquake history of the Central Altyn Tagh Fault, China, Geology, 29, 1051-1054.

Wells, D.L. and K. CopPERSMITH (1994): New empirical relationships among magnitude, rupture length, rupture width, rupture area, and surface displacement, Seismol. Soc. Am. Bull., 84, 974-1002.

WESNOUSKY, S.G. (1989): Seismicity and the structural evolution of strike-slip faults, in Fault Segmentation and Controls of Rupture Initiation and Termination, edited by D. SchwarTZ and R. Sibson, U.S. Geol. Surv. OpenFile Rep. 89-315, 409-431.

Wessel, P. and W.H.F. SMITH (1995): New version of the Generic Mapping Tools released, Eos, Trans. Am. Geophys. Un., 76 (33), p. 329.

YIN, A. and M. HARRISON (2000): Geologic evolution of the Himalayan-Tibetan orogen, Annu. Rev. Earth Planet. Sci., 28, 211-280. 